\title{
Smad3 Deficiency Counteracts Hepatocyte Apoptosis and Portal Fibrogenesis Induced By Bile Duct Ligation
}

\section{Misako Sato ${ }^{1,2}$, Kathleen C Flanders ${ }^{1 *}$, Tsutomu Matsubara ${ }^{3}$, Yasuteru Muragaki ${ }^{2}$, Shizuya Saika ${ }^{4}$ and Akira Ooshima ${ }^{1,2}$}

${ }^{1}$ Laboratory of Cancer Biology and Genetics, National Institutes of Health, Bethesda, Maryland, USA

${ }^{2}$ Department of Pathology, Wakayama Medical University, Wakayama, Japan

${ }^{3}$ Department of Anatomy and Regenerative Biology, Graduate School of Medicine, Osaka City University, Japan

${ }^{4}$ Department of Ophthalmology, Wakayama Medical University, Wakayama, Japan

\begin{abstract}
Objectives: Transforming Growth Factor (TGF)- $\beta$ is reportedly upregulated and plays a critical role in hepatic fibrogenesis. We aim to study the role of the Smad3, a key transcription factor downstream of TGF- $\beta$ receptors, signaling pathway in the pathogenesis of cholestatic liver injury induced by Bile Duct Ligation (BDL).

Materials and methods: We used mice lacking Smad3 (Smad3 $\left.{ }^{e \times 8 / / \times 8}\right)$, and their wild-type littermates to mode hepatic fibrosis using BDL. The underlying biology was investigated using histopathological examination and primary cultures of hepatocytes and biliary epithelial cells.

Results: Here we found that mice lacking Smad3 are protected against cholestatic liver injury induced by BDL as evidenced by the absence of hepatocyte apoptosis and portal fibroproliferative responses,including excessive collagen deposition and periductal myofibroblast proliferation. Smad3-null mice are also shown to reverse the hepatic TGF- $\beta 1$ upregulation after BDL. In vitro study demonstrates that TGF- $\beta 1$ expression in primary hepatocytes and intrahepatic biliary epithelial cells is amplified by TGF- $\beta 1$ itself through a positive feedback loop dependent on Smad3. Culture of primary hepatocytes confirms that Smad3 is indispensable for TGF- $\beta 1$-induced apoptosis.
\end{abstract}

Conclusions: The data demonstrate that Smad3 plays principal roles in the pathogenesis of BDL-induced cholestatic liver injury and suggest that intervention in this pathway may provide a novel therapeutic approach in the treatment of hepatic fibrosis.

Keywords: TGF- $\beta$; Smad3; Cholestatic liver injury; Bile duct ligation; Fibrosis; Apoptosis

\section{Introduction}

Hepatic fibrosis results from chronic injury due to various causes and ultimately leads to the irreversible and massive accumulation of Extracellular Matrix (ECM) proteins [1,2]. Although the morphological pattern of advanced hepatic fibrosis is similar, the characteristics of the pathogenetic insults may differ in the early stages of hepatic disease. For example, cholestatic liver injury produces portal fibrosis accompanied by periductal myofibroblast proliferation and necrotic or apoptotic periportal hepatocellular damage, leading to biliary cirrhosis characterized by nodule formation and scarring with portal-portal fibrous septa. In contrast, chronic viral hepatitis produces cirrhosis that features scarring with portal-central fibrous septa [3]. Several lines of evidence have pointed to Hepatic Stellate Cells (HSC) as being a principal culprit in hepatic fibrosis after transdifferentiating from quiescent HSC into fibrogenic myofibroblasts [4,5]. However, a variety of hepatic cell types other than HSC have recently been shown to undergo myofibroblastic transition, participating in hepatic fibrogenesis and tissue remodeling [2,3,6,7].

TGF- $\beta$ is the most potent fibrogenic cytokine that triggers the expression and accumulation of ECM proteins, and is reportedly upregulated during wound healing and tissue repair including hepatic fibrosis $[8,9]$. Aberrant expression of constitutively active TGF- $\beta 1$ in transgenic mice induces multiple tissue lesions including hepatocyte apoptosis and hepatic fibrosis as a consequence of the increase in TGF- $\beta 1$ $[10,11]$. TGF- $\beta$ type I and type II transmembrane receptor serine/ threonine kinases initiate intracellular signaling via transcription factors known as Smad2 and Smad3 proteins. They are phosphorylated by a ligand-activated TGF- $\beta$ type I receptor, after which they partner with Smad4 and translocate to the nucleus where they act as transcriptional regulators of target genes, including those essential for ECM production, apoptosis and Epithelial-Mesenchymal Transition (EMT) [12,13] Blockade of TGF- $\beta$ signaling by adenovirus-mediated dominantnegative expression of the type II TGF- $\beta$ receptor has been shown to prevent hepatic fibrosis and reverse hepatic dysfunction [14,15].

Although Smad2 and Smad3 share 92\% homology of their amino acid sequences, they have distinct characteristics in terms of their pathophysiological effects and roles in embryonic development $[16,17]$. In order to understand the mechanisms underlying the pathogenesis of cholestatic liver injury, we examined the cellular and molecular events involved in portal fibrosis and hepatocellular damage in relation to the intracellular signaling pathway for TGF- $\beta 1$. We also attempted to test our hypothesis that liver fibrogenesis may be diminished after Bile Duct Ligation (BDL) in a Smad3-dependent manner as occurs for lens epithelial cells [18] and renal tubular epithelial cells [19]. Targeted deletion of Smad2 causes early embryonic death, whereas ablation of Smad3 from mice ensures their survival for 1-8 months despite defective mucosal immunity [20]. We have utilized these mice $\left(\operatorname{Smad} 3^{\text {ex } 8 / \text { ex }}\right)$ and

*Corresponding author: Kathleen C Flanders, Laboratory of Cancer Biology and Genetics, National Institutes of Health, NCI/LCBG, BIdg 37/Rm 5046B, 37 Conven Dr, Bethesda, MD 20892, USA, Tel: 301-496-5453; Fax: 301-480-2772 ; E-mail: flanderk@mail.nih.gov

Received November 04, 2013; Accepted January 09, 2014; Published January 17,2014

Citation: Sato M, Flanders KC, Matsubara T, Muragaki Y, Saika S, et al. (2014) Smad3 Deficiency Counteracts Hepatocyte Apoptosis and Portal Fibrogenesis Induced By Bile Duct Ligation. J Liver 3: 145. doi:10.4172/2167-0889.1000145

Copyright: (C) 2014 Sato M, et al. This is an open-access article distributed unde the terms of the Creative Commons Attribution License, which permits unrestricted use, distribution, and reproduction in any medium, provided the original author and source are credited. 
their wild-type littermates to investigate the role of the Smad3 signaling pathway in the pathogenesis of cholestatic liver injury induced by BDL, a model of hepatic fibrosis.

\section{Methods}

\section{Animals and BDL model}

Smad3-null $\left(S m a d 3^{\text {ex/ } / x 8}\right)$ mice were generated as described elsewhere [20] and were used at the age of 6-8 weeks and 20-30 g in body weight. Under general anesthesia, a midline incision was made in the upper abdomen and the common bile duct was exposed and double-ligated. In sham-operated mice, the common bile duct was exposed but not ligated. For each experiment there were five mice in each of the BDL and sham groups for both the WT and null genotypes and the experiments were repeated three times. Five Fas-deficient lpr mice (Jackson Laboratories, Bar Harbor, ME) aged 5-6 weeks were used as the source of primary cultured hepatocytes. Mice were housed under standard conditions and all of the experimental procedures were approved by the Animal Care and Use Committee of Wakayama Medical University and by the National Cancer Institute Animal Care and Use Committee.

\section{Liver function analysis}

Blood samples were collected from the inferior vena cava at the time of euthanasia. The serum total bilirubin, serum Asparate Aminotransferase (AST) and serum Alanine Aminotransferase (ALT) levels were determined with assay kits according to the manufacturer's instructions (Wako Pure Chemical, Osaka, Japan).

\section{Primary cultures of hepatocytes and biliary epithelial cells}

Hepatocytes were isolated from mice as described previously [21]. Briefly, a cannula was inserted into the superior vena cava, while the inferior vena cava was ligated and the portal vein was amputated, allowing outflow of solution through the liver. Then the liver was perfused retrogradely through the superior vena cava with PBS containing $1 \mu \mathrm{M}$ EDTA for $3 \mathrm{~min}$ at $5 \mathrm{ml} / \mathrm{min}$ to purge intrahepatic blood, followed by pefusion with $0.5 \mathrm{mg} / \mathrm{ml}$ collagenase solution (Worthington Biochemical, NJ) in PBS containing $5 \mu \mathrm{M} \mathrm{CaCl}_{2}$ for 30 $\min$ at $2.5 \mathrm{ml} / \mathrm{min}$. Next, the liver was carefully dissected and placed into PBS containing $1 \mu \mathrm{M}$ EDTA. After removal of the hepatic capsule, parenchymal cells were gently scraped away from the portal tract strands which contain bile ducts, portal veins and hepatic arteries. Suspensions of parenchymal cells were centrifuged at $50 \times \mathrm{g}$ at $4^{\circ} \mathrm{C}$ for five min. The pellets were disaggregated by pipeting in William's medium E (Sigma-Aldrich, St. Louis MO) containing 10\% FBS, $1 \mu \mathrm{M}$ insulin, $1 \mu \mathrm{M}$ dexamethasone, 100 units $/ \mathrm{ml}$ penicillin and $0.1 \mathrm{mg} /$ $\mathrm{ml}$ streptomycin, and then centrifuged at $50 \times \mathrm{g}$ at $4^{\circ} \mathrm{C}$ for five min. Trituration of the pellets and centrifugation were repeated five times. After the cell suspension was passed through a $40-\mu \mathrm{m}$ cell strainer (BD Biosciences, Bedford, MA), cells were plated onto type I collagencoated dishes (Iwaki-Asahi Techno Glass, Tokyo, Japan) or two-well chamber slides (Becton Dickinson Labware, NJ), incubated at $37^{\circ} \mathrm{C}$ under $5 \% \mathrm{CO}_{2}$ for 2 hours to allow attachment and then the medium was exchanged. For isolation of biliary epithelial cells, the portal tract strands removed from the collagenase-perfused liver were further digested in $0.25 \%$ trypsin solution (Gibco BRL, Grand Island, NY) at $37^{\circ} \mathrm{C}$ under $5 \% \mathrm{CO}_{2}$ for 2 hours with occasional shaking. Under a dissecting microscope, the gallbladder and extrahepatic bile ducts were removed, and the intrahepatic bile ducts were separated from connective tissues, portal veins, and hepatic arteries. The bile ducts thus isolated were minced into small pieces in DMEM containing 10\% FBS,
100 units $/ \mathrm{ml}$ penicillin and $0.1 \mathrm{mg} / \mathrm{ml}$ streptomycin, and vigorously pipetted. Then the cell suspension was filtered through a $70-\mu \mathrm{m}$ strainer (BD Biosciences) and plated onto culture dishes (NalgeNunc International, Naperville, IL) or 2-well chamber slides (Nunc Lab-Tek II-CC2; NalgeNunc International), with medium changes every two days. Experiments were carried out in serum-free medium. EMT and apoptosis were induced by the addition of $10 \mathrm{ng} / \mathrm{ml}$ TGF- $\beta 1$ (R\&D Systems, Minneapolis, MN). Mouse monoclonal anti-TGF- $\beta 1,-\beta 2$ and $-\beta 3$ antibody (clone 1D11; R\&D Systems) was used at a concentration of $20 \mu \mathrm{g} / \mathrm{ml}$ to neutralize endogenous TGF- $\beta$, with mouse IgG (SigmaAldrich) as the control.

\section{Histology and immunofluorescence}

Histological sections ( $4 \mu \mathrm{m}$ thick) were prepared from paraffin blocks of tissues fixed in $4 \%$ paraformaldehyde in $0.1 \mathrm{M}$ phosphate buffer, $\mathrm{pH}$ 7.4. Cryosections ( $4 \mu \mathrm{m}$ thick) and chamber slides were fixed in cold acetone for five min and subjected to indirect immunofluorescence with anti-E-cadherin (clone DECMA-1; SigmaAldrich), anti- $\alpha$-SMA (clone 1A4; NeoMarkers, Fremont, CA), antimouse type I collagen (Southern Biotechnology, Birmingham, AL), anti-mouse F4/80 antigen (clone A3-1; BMA, Augst, Switzerland), and anti-cytokeratin 7 (Sc-23876; Santa Cruz Biotechnology, Santa Cruz, CA). The secondary antibodies were FITC-anti-rat IgG (SigmaAldrich), TRITC-anti-mouse IgG (Sigma-Aldrich), and Cy3-anti-goat IgG (Sigma-Aldrich). Primary antibody was omitted as a negative control.

\section{Apoptosis and cell proliferation}

For detection of apoptotic cells using the TUNEL assay, paraffin sections ( $4 \mu \mathrm{m}$ thick) and chamber slides fixed in $4 \%$ paraformaldehyde in $0.1 \mathrm{M}$ phosphate buffer, $\mathrm{pH} 7.4$ were processed by an ApoTag fluorescence in situ apoptosis detection kit (Chemicon International, Temecula, CA) according to the manufacturer's instructions. Coverslips were mounted onto slides using Vectashield with DAPI (H1200; Vector Laboratories, Burlingame, CA). The extent of apoptosis in tissue sections was determined from the number of TUNEL-positive cells per unit area. Additionally, cells were stained with antibody to cleaved caspase-3 (Asp 175) (Clone 5A1E; Cell Signaling Technology, Danvers, MA). A cell death detection ELISA kit (Roche Applied Science, Indianapolis, IN) was used to identify internucleosomal fragmentation of DNA in lysates of primary hepatocytes in the presence or absence of TGF- $\beta 1$. For the cell proliferation assay, primary hepatocytes were treated with BrdU labeling reagent at a final concentration of $10 \mu \mathrm{M}$ for 2 hours using a cell proliferation ELISA Biotrak system kit (Amersham Biosciences, Buckingshire, UK).

\section{Immunoblotting}

Cells and tissues were lysed in buffer containing 1\% Nonidet P-40, $25 \mathrm{mM}$ Tris- $\mathrm{HCl}, \mathrm{pH} 7.5,150 \mathrm{mM} \mathrm{NaCl}, 10 \mathrm{mM}$ EDTA and 1:50 dilution of a protease inhibitor (Sigma-Aldrich). Proteins were separated by SDS-PAGE, transferred to nitrocellulose membranes, and blocked with 5\% skim milk in PBS. After incubation with primary antibodies for E-cadherin (clone 36, Transduction Laboratories, Lexington, KY), a-SMA (clone 1A4, Neo Markers), and actin (Sc-1616; Santa Cruz Biotechnology), blots were reacted with the peroxidase-conjugated goat anti-mouse IgG secondary antibody (Sigma-Aldrich) and the reaction products were developed with ECL (Amersham Biosciences).

\section{In situ hybridization}

Digoxigenin-11-UTP-labelled antisense riboprobes were prepared with an RNA-labelling kit (Roche Diagnostics-Boeringer Mannheim, 
Citation: Sato M, Flanders KC, Matsubara T, Muragaki Y, Saika S, et al. (2014) Smad3 Deficiency Counteracts Hepatocyte Apoptosis and Portal Fibrogenesis Induced By Bile Duct Ligation. J Liver 3: 145. doi:10.4172/2167-0889.1000145

Page 3 of 10

Indianapolis, IN) for in situ hybridization as described elsewhere [22]. Mouse $\alpha$ SMA, collagen $\alpha 1(\mathrm{I})$ chain, Snail and TGF- $\beta 1$ RNA probes were transcribed from the PCR products using the following primers from complete mouse RNA: $\alpha$-SMA (GenBank accession number NM_007392), 5'-CTGCTCTGCCTCTAGCACAC-3' and 5'-TTAAGGGTAGCACATGTCTG-3'; collagen $\alpha 1(\mathrm{I})$ chain, (NM007742), 5'-TGGAGGGAGTTTACACAGAAG-3' and 5'-AAGAAGCACGTCTGGTTTGG-3'; Snail (XM_123964), 5'-ACACTGGTGAGAAGCCATTC-3' and 5'-AGTTCTATGGCTCGAAGCAG-3'; TGF$\beta 1$ (N13177), 5'-CACGTGGAAATCAACGGGAT-3' and 5'-GCGCACAATCATGTTGGACA-3'. Sections (4 $\mu$ m thick) were processed with a Ventana HX system (Ventana Medical Systems, Tucson, AZ) according to the manufacturer's instruction. After hybridization, the sections were washed three times in $1 \mathrm{x}$ SCC $(0.15 \mathrm{M}$ sodium chloride and 0.015 $\mathrm{M}$ sodium citrate, $\mathrm{pH} 7.0$ ) high stringency solution at $65^{\circ} \mathrm{C}$ and then incubated with alkaline phosphatase-conjugated anti-digoxigenin Fab fragments (Roche Diagnostics). Color was developed with a freshly prepared substrate solution of nitro blue tetrazolium and 5-bromo4-chloro-3-indolyl phosphate (Digoxigenin detection kit; Roche Diagnostics). Hybridizations with sense strands were used as a negative control and showed no staining in all cases.

\section{Northern blotting}

Total RNA was extracted with TRIzol reagent (Invitorogen, Carlsbad, CA). RNA $(20 \mu \mathrm{g} / \mathrm{lane})$ was separated by $1 \%$ agaroseformaldehyde gel electrophoresis and transferred to Hybond-XL nylon membranes (Amersham Biosciences). Membranes were hybridized with cDNA probes for mouse Snail and TGF- $\beta 1$ mRNA labeled with $\left[{ }^{32} \mathrm{P}\right] \mathrm{dCTP}$ by random-primed DNA synthesis using the same primers as listed above (Rediprime II; Amersham Biosciences). Membranes were exposed to X-ray film at $-80^{\circ} \mathrm{C}$ for 2 to 3 days. Band intensities were normalized to those of the $28 \mathrm{~S}$ and $18 \mathrm{~S}$ ribosomal bands after ethidium bromide staining.

\section{Immunoassay of TGF- $\beta 1$}

Proteins were extracted from liver tissues in $20 \mathrm{mM}$ Tris- $\mathrm{HCl}, \mathrm{pH}$ 7.5 containing $2 \mathrm{mM} \mathrm{NaCl}, 0.1 \%$ Tween $80,1 \mathrm{mM}$ EDTA and $1 \mathrm{mM}$ PMSF, and cell culture medium for determination of the active TGF- $\beta 1$ levels with a Quantikine TGF- $\beta 1$ assay kit (R\&D Systems). Samples were acidified for the total TGF- $\beta 1$ assay. Values were expressed as pg/ $\mathrm{mg}$ protein for the protein extract or $\mathrm{pg} /$ cell for culture medium.

\section{Hydroxyproline assay}

Tissue samples were hydrolyzed in $6 \mathrm{~N} \mathrm{HCl}$ for 12 hours at $110^{\circ} \mathrm{C}(50$ $\mathrm{mg} / \mathrm{ml}$ ). The hydroxyproline content of the supernatant was assayed by the method described elsewhere [23]. Values were expressed as $\mu \mathrm{g} / \mathrm{mg}$ tissue.

\section{Statistics}

Results were expressed as the mean \pm standard deviation. Student's unpaired t-test and multiple analyses of variance by Scheffe's method were used for statistical comparisons. A probability $(\mathrm{P})$ value of less than 0.05 was considered to indicate statistical significance.

\section{Results}

Hepatic architecture and function are preserved after BDL in Smad3-null mice

Seven days after BDL in wild-type mice (Figure 1A), the portal
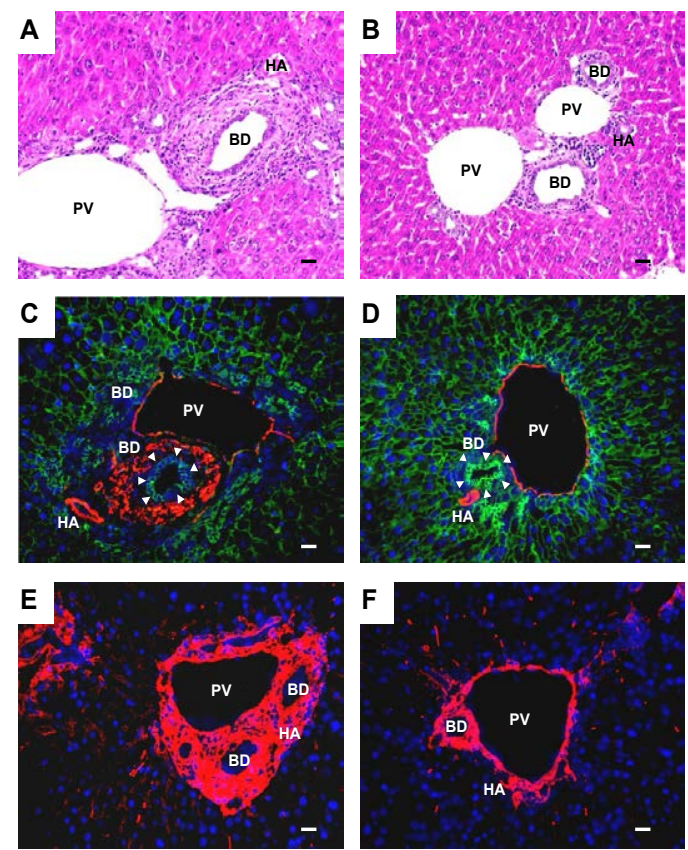
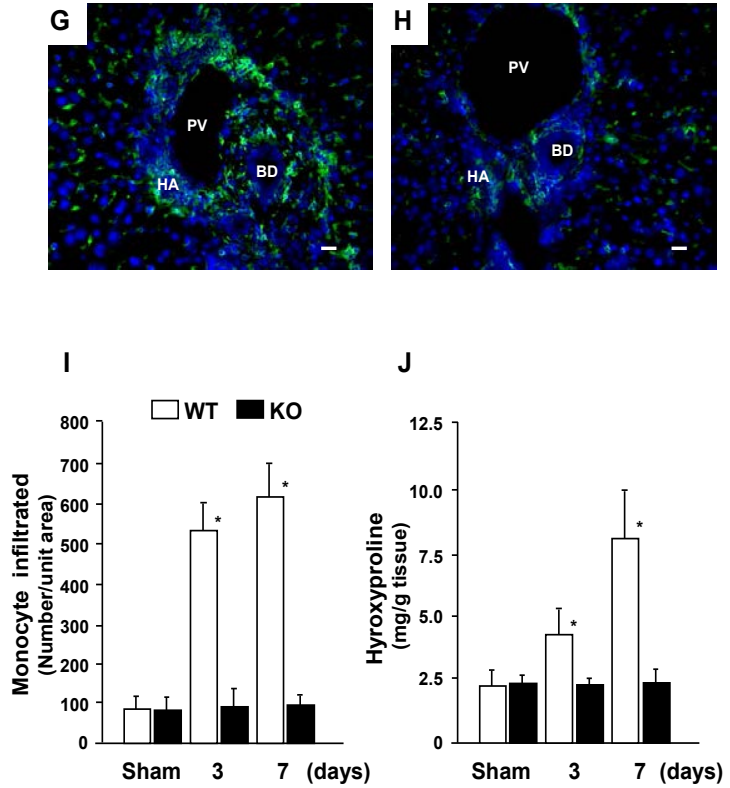

Figure 1: Smad3-null mice are protected from cholestatic liver injury induced by BDL. (A-H) All images display representative areas of livers in wild-type (A, C, E, G) and Smad3-null mice (B, D, F, H) at day 7 after BDL.All panels are representative of 5 samples/group. Scale bar: $20 \mu \mathrm{m}$. BD, bile duct; PV, portal vein; HA, hepatic artery. (A and B) H \& E staining in wild-type (A) and Smad3-null mice (B). (C and D) Dual immunofluorescence for E-cadherin (green) and $\alpha$-SMA (red) in the livers from a wild-type mouse $(C)$ and a Smad3-null counterpart (D). DAPI (blue) was used for nuclear staining. White arrowheads indicate biliary epithelial cells. (E and F) Immunofluorescenece for type I collagen (red) in the livers of a wild-type mouse (E) and a Smad3-null counterpart (F). (G and H) Immunofluorescence for F4/80 antigen (green), a mouse monocyte marker, in the livers of a wild-type mouse (G) and a Smad3-null counterpart (H).(I) Number of F4/80 antigen-positive monocytes per unit area in the livers of wild-type (WT) and Smad3-null mice (KO) at day 3 and 7 after BDL, and in sham-operated mice (Sham). (J) Hydroxyproline content in the livers of wild-type (WT) and Smad3-null mice (KO) at day 3 and 7 after BDL, and sham-operated mice (Sham). Results for (I) and (J) are the mean \pm standard deviation for 5-6 samples/group. ${ }^{\star} P<0.01$ compared with KO or Sham. 
tracts were markedly expanded by dense, concentric fibrosis (Figure 1E) with prominent proliferation of periductal mesenchymal cells (Figure 1C) and influx of inflammatory mononuclear cells (Figure 1G), whereas the hepatic architecture of Smad3-null counterparts was well preserved (Figure 1B) except for influx of a few scattered mononuclear cells in the portal tracts (Figure $1 \mathrm{H}$ ). These results indicate that the portal fibroproliferative response after BDL is dependent on the Smad3 signaling pathway. Dual immunofluorescence demonstrates that the appearance of periductal mesenchymal cells identified as myofibroblasts by the positive immunoreaction to $a$-Smooth Muscle Actin ( $\alpha$-SMA) coincides with a marked reduction in E-cadherin of the bile duct epithelia in wild-type mice at day 7 after BDL (Figure 1C). Smad3-null counterparts, on the other hand, maintain a prominent E-cadherin expression without myofibroblast proliferation (Figure 1D). An excessive amount of type I collagen was deposited in the portal tracts of wild-type mice (Figure 1E), but not Smad3-null mice at day 7 after BDL (Figure 1F). Hepatic collagen deposition in the wild-type mice as estimated from the hydroxyproline content was increased by two- and three-fold compared with that in Smad3-null counterparts at day 3 and 7 after BDL, respectively (Figure 1J). Greater influx of monocytes (detected by immune staining for F4/80 antigen) into the portal tracts was noted in wild-type mice (Figure $1 \mathrm{G}$ ) than in their Smad3-null counterparts at day 7 after BDL (Figure 1H). The number of monocytes per unit area was increased by 5.6- and 6.5-fold in the livers of wild-type mice compared with Smad3-null mice at day 3 and 7 after BDL, respectively (Figure 1I). Serum total bilirubin, and AST and ALT, marker enzymes for hepatocellular injury, increased in a time-dependent manner after BDL (Figure 2A-C). However, the serum AST and ALT levels of Smad3-null mice were far lower than those of wild-type counterparts despite similar levels of hyperbilirubinemia in these animals (Figure 2A-C). These results indicate that the abrogation of Smad3 signaling greatly reduces BDL-induced hepatocellular injury and hepatic dysfunction.

\section{BDL-induced hepatic upregulation of TGF- $\beta 1$ is Smad3- dependent}

The levels of active TGF- $\beta 1$ and the expression of TGF- $\beta 1$ mRNA in the liver of wild-type mice markedly exceeded those in Smad3null counterparts at day 3 and 7 after BDL (Figure 3A and B). In situ hybridization revealed the enhanced expression of TGF- $\beta 1$ mRNA by cells in the portal tracts in wild-type mice at day 7 after BDL (Figure 3C). Examination of sections under higher magnification showed increased expression in biliary epithelial cells, periductal mesenchymal cells, infiltrating mononuclear cells which were mostly monocytes, and periportal hepatocytes. In Smad3-null counterparts, there was no appreciable expression of TGF- $\beta 1 \mathrm{mRNA}$ except for a faint signal in the biliary epithelial cells (Figure 3D), indicating that hepatic upregulation of TGF- $\beta 1$ in response to BDL is dependent on Smad3 signaling. In each case, hybridization with the sense probe showed no staining (data not shown).

\section{Auto induction of TGF- $\beta 1$ depends on Smad3 signaling in primary hepatocytes and biliary epithelial cells}

The level of total TGF- $\beta 1$ in serum-free medium of primary hepatocytes (Figure 4A) and biliary epithelial cells (Figure 4C) increased over time. More than three times the amount of TGF- $\beta 1$ was released into the culture medium by wild-type cells compared with Smad3-null counterparts at the time point of 48 hours (Figure $4 \mathrm{~A}$ and $\mathrm{C}$ ).

Addition of TGF- $\beta$ to the culture medium upregulated TGF- $\beta 1$ mRNA expression in both wild-type hepatocytes and biliary epithelial cells, but not Smad3-null counterparts (Figure 4B and D respectively), indicating that upregulation of TGF- $\beta 1$ mRNA by TGF- $\beta 1$ itself (auto induction) is mediated through Smad3 signaling.

\section{TGF- $\beta 1 /$ Smad3 signaling is essential for hepatocyte apoptosis and growth inhibition in vitro}

A greater number of cells, mostly hepatocytes, underwent apoptosis as detected by the TUNEL method in wild-type mice at day 3 and 7 after BDL than in Smad3-null counterparts (Figure 5A, $\mathrm{B}$, and $\mathrm{E}$ ). This result was confirmed by staining with an antibody to cleaved caspase- 3 (Figure $5 \mathrm{C}$ and D). To ascertain whether hepatocyte apoptosis is mediated through TGF- $\beta 1 / \mathrm{Smad} 3$ signaling, primary cultures of hepatocytes were obtained from the livers of wild-type and Smad3-null mice. Treatment with TGF- $\beta 1$ induced apoptosis of hepatocytes from wild-type mice at the time point of 48 hours as shown by nuclear fragmentation, cell detachment (Figure 6A and $\mathrm{B}$ ), and TUNEL positivity (Figure $6 \mathrm{E}$ and $\mathrm{F}$ ), whereas no apoptosis occurred in Smad3-null hepatocytes (Figure 6C, D, G and H).
A

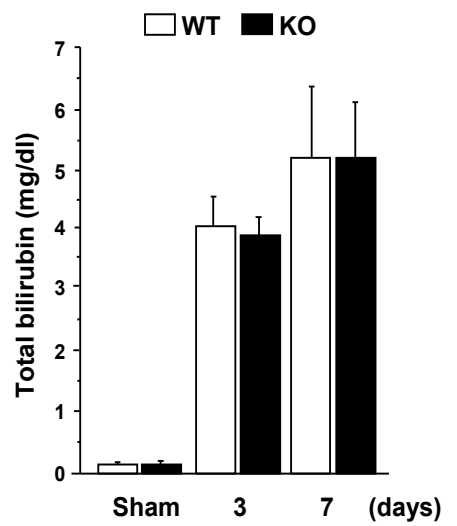

B

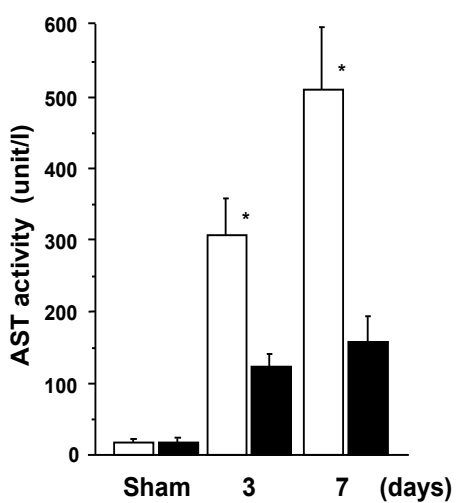

C

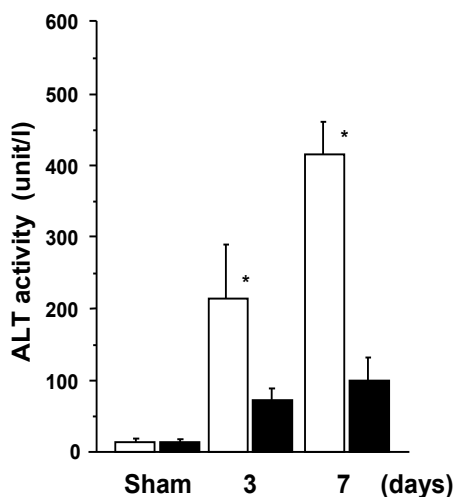

Figure 2: Hepatic dysfunction after BDL is markedly attenuated in Smad3-null mice. (A) Serum total bilirubin level in wild-type (WT) and Smad3-null mice (KO) at day 3 and 7 after BDL and in sham-operated mice (Sham). (B and C) Serum levels of Asparate Aminotransferase (AST) (B) and alanine aminotransferase (ALT) (C) in Wild-Type (WT) and Smad3-null mice (KO) at day 3 and 7 after BDL, and in sham-operated mice (Sham). Results in each panel are the mean \pm standard deviation for 6 samples/group. * $P<0.01$ compared with KO or Sham. 
Citation: Sato M, Flanders KC, Matsubara T, Muragaki Y, Saika S, et al. (2014) Smad3 Deficiency Counteracts Hepatocyte Apoptosis and Portal Fibrogenesis Induced By Bile Duct Ligation. J Liver 3: 145. doi:10.4172/2167-0889.1000145
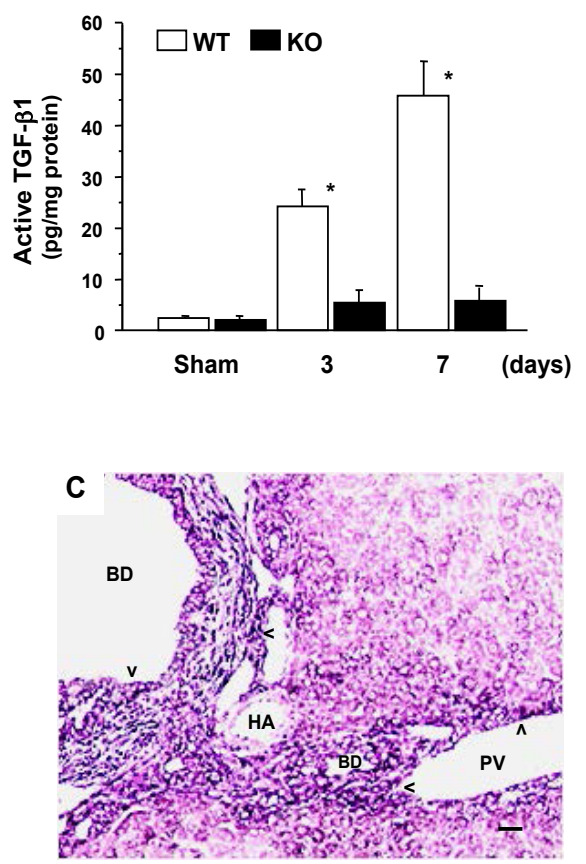
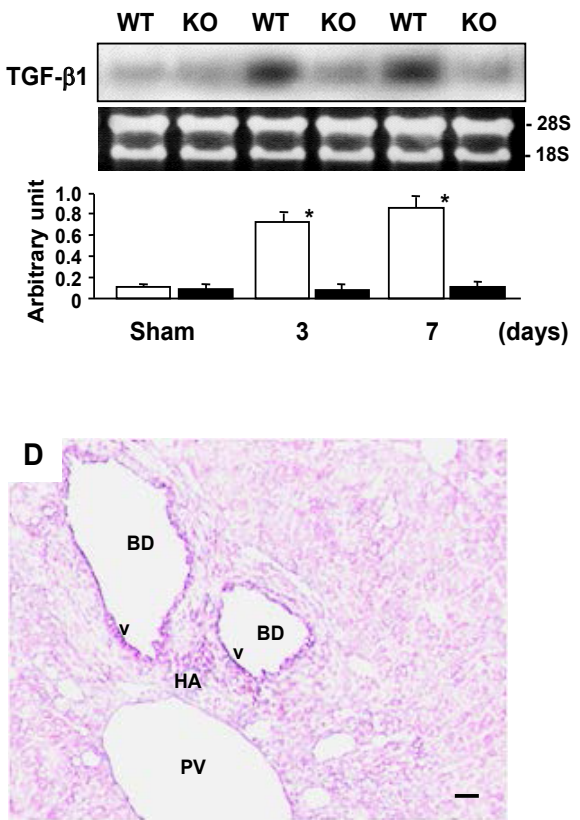

Figure 3: Upregulation of hepatic TGF- $\beta 1$ after BDL is abolished in Smad3-null mice. (A) Hepatic content of active TGF- $\beta 1$ at day 3 and 7 after BDL in Wild-Type (WT) and Smad3-null mice (KO), and sham-operated mice (Sham). (B) Northern blot analysis of TGF- $\beta 1$ mRNA in the livers of Wild-Type (WT) and Smad3-null mice $(\mathrm{KO})$ at day 3 and 7 after BDL, and in sham-operated mice (Sham). Results in A and B are the mean \pm standard deviation for 5 samples/group. ${ }^{\star} P<0.01$ compared with KO or Sham. (C and D) In situ hybridization of TGF- $\beta 1$ mRNA in the livers of a wild-type mouse (C) and a Smad3-null counterpart (D) at day 7 after BDL.Purple signal (arrowhead) with nuclear fast red counterstain. Scale bar: $20 \mu \mathrm{m}$. BD, bile duct; PV, portal vein; HA, hepatic artery.

A

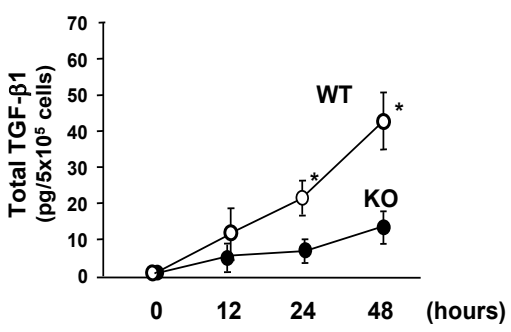

C

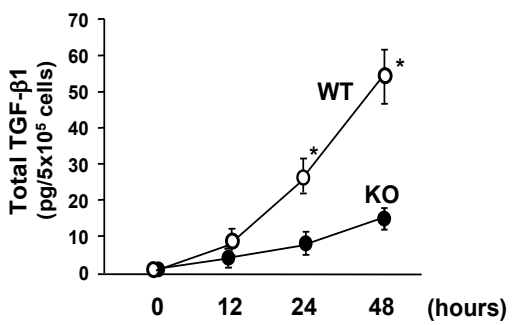

B

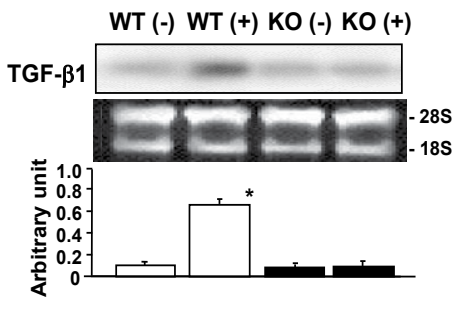

D

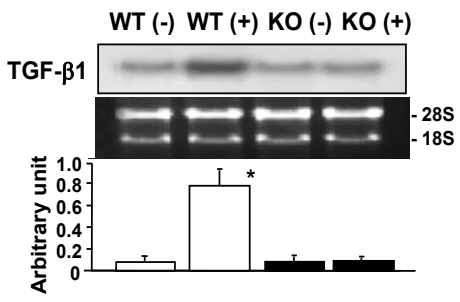

Figure 4: Smad3-mediated autoinduction of TGF- $\beta 1$ in primary hepatocytes and intrahepatic biliary epithelial cells. (A and C) Total TGF- $\beta 1$ level in the culture medium of primary hepatocytes (A) and biliary epithelial cells (C) from Wild-Type (WT) and Smad3-null mice (KO). Results are the mean \pm standard deviation for 4-5 samples/ time point and genotype. ${ }^{*} P<0.01$ compared with KO. (B and D) Northern blot analysis of TGF- $\beta 1$ mRNA expression in primary hepatocytes (B) and biliary epithelial cells (D) in the absence (-) or presence (+) of TGF- $\beta 1(10 \mathrm{ng} / \mathrm{ml})$ for 12 hours. Cells without TGF- $\beta 1$ were also treated with a neutralizing antibody directed against TGF- $\beta(20 \mu \mathrm{g} / \mathrm{ml})$ to exclude any effect of endogenous TGF- $\beta$. The same amount of normal lgG was added to the culture medium of TGF- $\beta 1$-treated cells. Results are the mean \pm standard deviation for 5 samples/group. ${ }^{*} P<0.01$ compared with WT $(-)$, KO (-) or KO (+).

Moreover, TGF- $\beta 1$ caused dose-dependent apoptosis of wild-type hepatocytes, but again no apoptosis was induced in Smad3-null counterparts (Figure 6I). Primary culture of hepatocytes further demonstrated that TGF- $\beta 1$ represses cell growth in a time- (12 and 24 h) and dose-dependent manner through Smad3 signaling (Figure 6J) as measured by BrdU incorporation. 
Citation: Sato M, Flanders KC, Matsubara T, Muragaki Y, Saika S, et al. (2014) Smad3 Deficiency Counteracts Hepatocyte Apoptosis and Portal Fibrogenesis Induced By Bile Duct Ligation. J Liver 3: 145. doi:10.4172/2167-0889.1000145
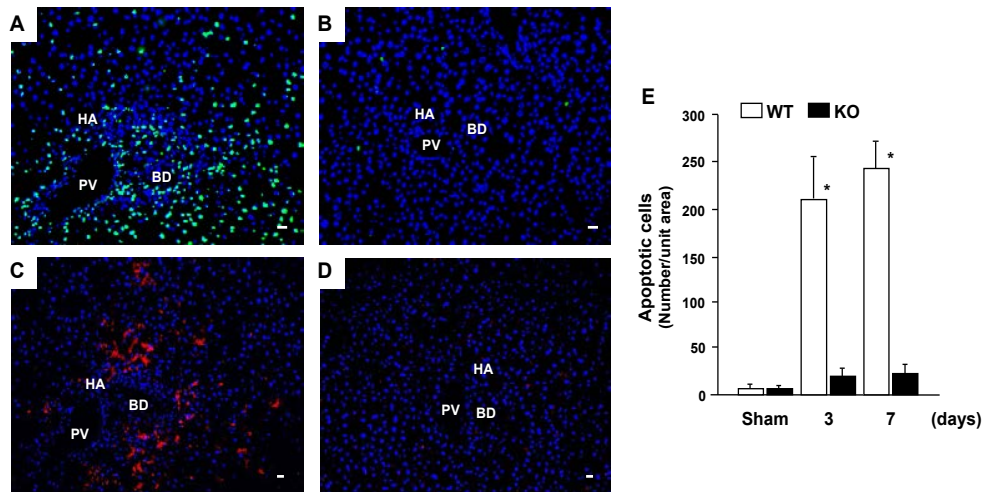

Figure 5: Hepatic apoptosis after BDL is abolished in Smad3-null mice. (A-D) Apoptotic cells are detected by the TUNEL method (green) or immunofluorescence for cleaved caspase-3 (red) in the livers of a wild-type mouse (A, C) and a Smad3-null counterpart (B, D) at day 7 after BDL. DAPI (blue) was used for nuclear staining. Representative of 5 samples/group Scale bar: $20 \mu \mathrm{m}$. BD, bile duct; PV, portal vein; HA, hepatic artery. (E) Number of apoptotic cells per unit area in the livers of wildtype (WT) and Smad3-null mice (KO) at day 3 and 7 after BDL, and sham-operated mice (Sham) as determined by TUNEL staining. Results are the mean \pm standard deviation for 5 samples/timepoint and genotype. ${ }^{*} P<0.01$ compared with $\mathrm{KO}$ or Sham.
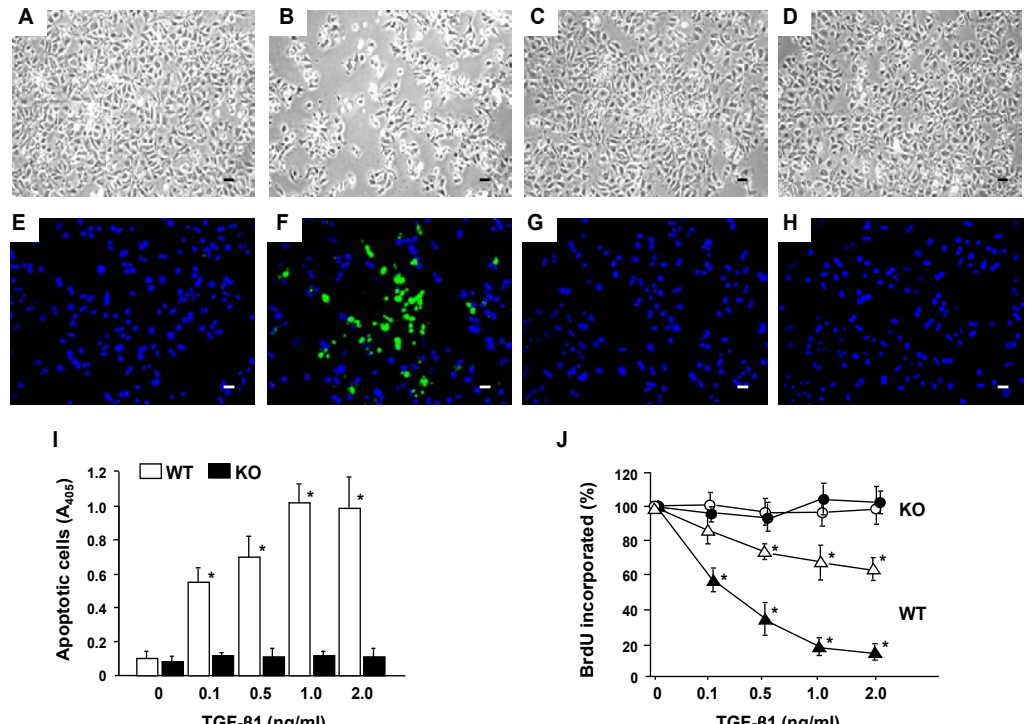

$\mathrm{J}$

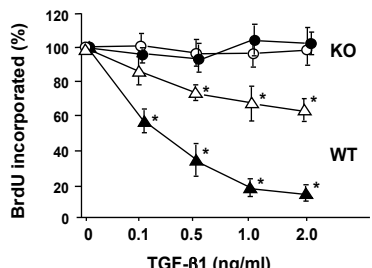

Figure 6: TGF- $\beta 1$-induced apoptosis and growth inhibition of primary hepatocytes are mediated via Smad3 signaling. (A-H) Phase-contrast images (A-D) and TUNEL staining $(E-H)$ of primary hepatocytes from wild-type ( $A, B, E$ and $F$ ) and Smad3-null mice $(C, D, G$ and $H)$ incubated in the absence $(A, C$, $E$ and $G)$ or presence (B, $\mathrm{D}, \mathrm{F}$ and $\mathrm{H})$ of TGF- $\beta 1(10 \mathrm{ng} / \mathrm{ml})$ for 48 hours. DAPI was used for nuclear staining. Scale bar: $20 \mu \mathrm{m}$. (I) TGF- $\beta 1$-induced apoptosis in the primary hepatocytes from Wild-Type (WT) and Smad3-null mice (KO) at 24 hours. (J) TGF- $\beta 1$-induced growth inhibition of hepatocytes from wild-type (WT, triangles) and Smad3-null mice (KO, circles) at 12 (open circles and triangles) and 24 hours (solid circles and triangles). Results in (I) and (J) are the mean \pm standard deviation for five samples/dose and genotype. ${ }^{*} P<0.01$ compared with $\mathrm{KO}$.

\section{TGF- $\beta$ /Smad3 signal induces EMT of intrahepatic biliary epithelial cells in vitro}

We noticed that E-cadherin expression of the bile duct epithelium is markedly reduced or partially lost after BDL in wild-type mice, but not in Smad3-null counterparts (Figure 1C and D). Additional studies showed concurrent expression of Snail mRNA in the bile duct epithelium of wild-type mice (Figure 9A and B). The Snail superfamily of zinc-finger transcription factors are known to be potent repressors of the E-cadherin gene and have been implicated in both embryonic and injury-induced EMT [24,25]. In order to confirm the occurrence of EMT, primary cultures of biliary epithelial cells were obtained from isolated intrahepatic bile ducts of wild-type and Smad3-null mice. Experiments were conducted when colonies of cobblestone-shaped epithelial cells grew after 6-7 days of culture. Judging from the positive immunoreaction to cytokeratin 7 , a marker of biliary epithelial cells, or E-cadherin, more than $95 \%$ of the cells were estimated to be derived from biliary epithelial cells (not shown). Treatment of wildtype cells with TGF- $\beta 1$ for 48 hours resulted in a change to spindleshaped, fibroblastic cells (Figure 7A and B), whereas their Smad3null counterparts preserved an epithelial phenotype (Figure 7C and D) irrespective of TGF- $\beta 1$ treatment. Dual immunofluorescence demonstrated that E-cadherin expression was markedly reduced along with de novo expression of a-SMA after stimulation of wildtype cells with TGF- $\beta 1$ for 48 hours (Figure $7 \mathrm{E}$ and F), but these changes did not occur in Smad3-null counterparts (Figure 7G and $\mathrm{H})$. Immunoblot analyses of E-cadherin and $\alpha$-SMA in the lysates of wild-type and Smad3-null cells grown in the absence or presence of 
Citation: Sato M, Flanders KC, Matsubara T, Muragaki Y, Saika S, et al. (2014) Smad3 Deficiency Counteracts Hepatocyte Apoptosis and Portal Fibrogenesis Induced By Bile Duct Ligation. J Liver 3: 145. doi:10.4172/2167-0889.1000145
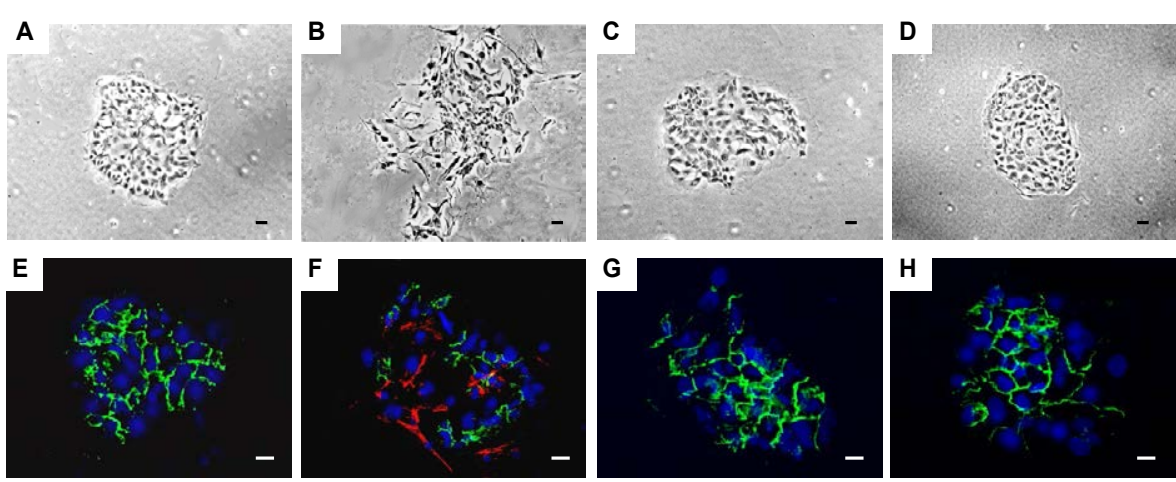

I
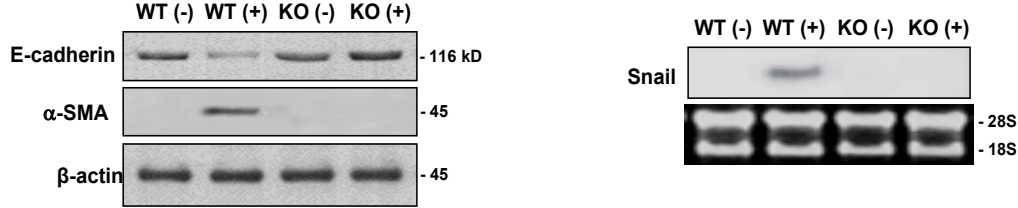

Figure 7: TGF- $\beta 1$-induced EMT of primary intrahepatic biliary epithelial cells is mediated through Smad3 signaling. (A-H) Phase-contrast images (A-D) and dual immunofluorescence (E-H) for E-cadherin (green) and $\alpha$-SMA (red). The primary intrahepatic biliary epithelial cells were obtained from wild-type (A, $B$, $E$ and $F$ ) and Smad3-null mice (C, D, G and H) and incubated in the absence (A, C, E and G) or presence (B, D, F and H) of TGF- $\beta 1$ (10 ng/ml) for 48 hours. DAPI (blue) was used for nuclear staining. Images are representative of 5 experiments/group.(I) Immunoblotting for E-cadherin and $\alpha$-SMA in protein extracted from primary cultures of the biliary epithelial cells of Wild-Type (WT) or Smad3-null mice (KO) after incubation for 48 hours in the absence (-) or presence (+) of TGF- $\beta 1$ (10 ng/ml). (J) Northern blotting of Snail mRNA in biliary epithelial cells from wild-type (WT) and Smad3-null mice (KO) after culture for 48 hours in the absence (-) or presence (+) of TGF- $\beta 1$ $(10 \mathrm{ng} / \mathrm{ml})$ for 48 hours. Similar results were obtained from 4 additional experiments.
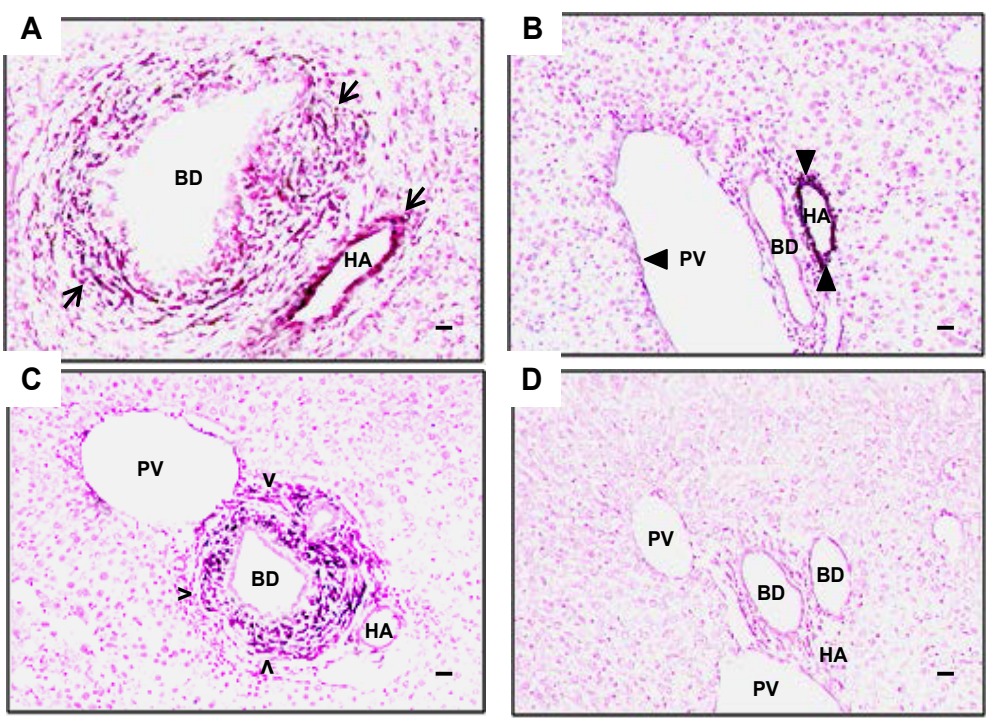

Figure 8: In situ hybridization of $\alpha-S M A$ and collagen $\alpha 1(\mathrm{I})$ chain mRNA in the livers after BDL (A-D). Expression of $\alpha-S M A$ mRNA (A and B), type I collagen (C and $D$ ) in the livers of wild-type (A and C) and Smad3-null mice (B and D) at day 7 after BDL. Purple signal with nuclear fast red counterstain.Arrows, $\alpha$-SMA signal in WT mice; arrowheads, collagen signal in WT mice; Solid arrowheads, $\alpha-S M A$ signal in Smad3-null mice. Scale bar: $20 \mu \mathrm{m}$. BD, bile duct; PV, portal vein; HA, hepatic artery. Similar results were obtained from 5 additional experiments.

TGF- $\beta 1$ for 48 hours are substantially in agreement with the results of dual immunofluorescence (Figure 7I and E-H). Northern blot analysis revealed that Snail mRNA expression is restricted to wild-type cells at the time point of 48 hours after TGF- $\beta 1$ stimulation (Figure 7J).

\section{Loss of Smad3 attenuates TGF- $\beta 1$-induced hepatic fibrosis}

In addition to the substantial reduction of E-cadherin from the bile duct epithelium, the proliferation of periductal myofibroblasts was a noticeable morphological feature in the livers of wild-type mice, but not Smad3-null counterparts after BDL (Figure 1C and D). In situ hybridization showed that the periductal mesenchymal cells of wildtype mice became positive for $\alpha$-SMA and collagen $\alpha 1$ (I) chain mRNA in the immediate vicinity of the bile duct epithelia and extended to the periphery of the portal tracts (Figure $8 \mathrm{~A}$ and $\mathrm{C}$ ), whereas no positive signals, apart from the expected signal for a-SMA mRNA in the smooth muscle cells of the hepatic artery and portal vein, were found in Smad3- 

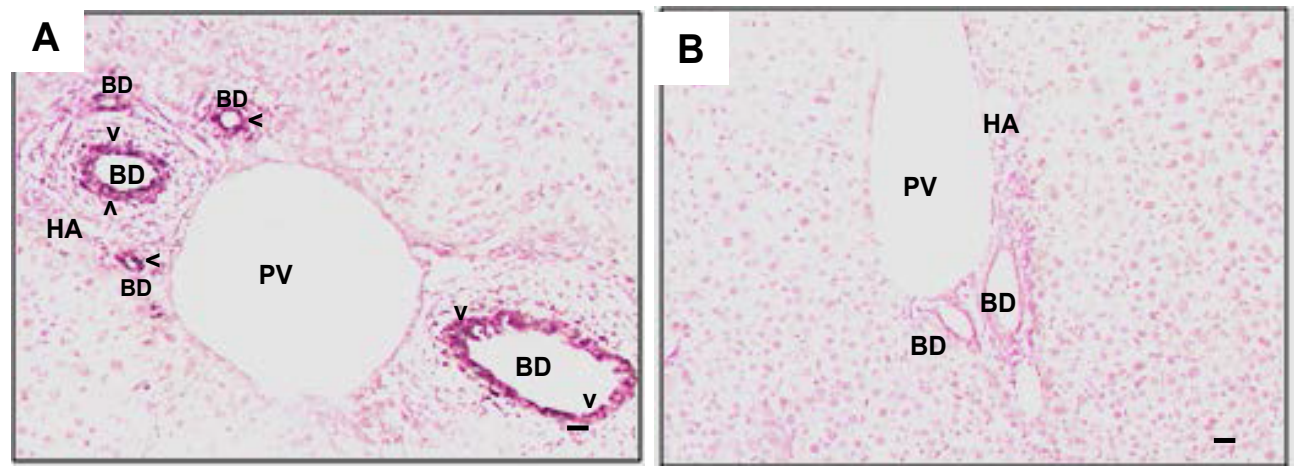

Figure 9: In situ hybridization of Snail in the livers after BDL.Expression of Snail mRNA in the livers of wild-type (A) and Smad3-null mice (B) at day 7 after BDL.Purple signal (arrowheads) in bile duct epithelium of WT mice with nuclear fast red counterstain. Scale bars represent $20 \mu \mathrm{m}$. BD, bile duct; PV, portal vein; HA, hepatic artery.Similar results were obtained from 4 additional experiments.

null counterparts at day 7 after BDL (Figure $8 \mathrm{~B}$ and $\mathrm{D}$ ). These findings indicate that TGF- $\beta 1$-induced liver fibrogenesis is dependent on a Smad3-specific mechanism.

\section{Discussion}

TGF- $\beta$ plays a critical role in fibrotic disorders [8] including hepatic injury in both humans [26] and animals [27] and previous work [28] has shown increased activation of Smad3 signaling in the liver up to 5 wks following bile duct ligation. Our present study shows that this Smad3 signaling is essential for BDL-induced upregulation of hepatic TGF- $\beta 1$ expression. Investigation of purified isolates of hepatic cells has previously shown that TGF- $\beta$ expression is elevated in hepatocytes and HSC after partial hepatectomy and BDL, respectively [29]. We now present additional evidence that biliary epithelial cells, periductal mesenchymal cells and periportal hepatocytes from wild-type mice display prominent expression of TGF- $\beta 1$ after BDL. The lack of TGF- $\beta 1$ induction in Smad3-null mice implies that the BDL-induced increase of TGF- $\beta 1$ is mediated through a positive-feedback loop that depends on Smad3, similar to that previously reported in monocytes [30] and fibroblasts [31]. Autoinduction of TGF- $\beta 1$ in hepatocytes and biliary epithelial cells from wild-type mice may further amplify TGF- $\beta 1$ expression during BDL, providing a self-perpetuating element to the process of cholestatic liver injury leading to biliary cirrhosis. TGF- $\beta$ is one of the most potent chemotactic cytokines for monocytes [32]. The significant reduction of monocyte infiltration into the livers of Smad3-null mice after BDL indicates that both endogenous TGF- $\beta 1$ and the Smad3 pathway are involved in the influx of inflammatory cells in this injury model. Since Smad3-null monocytes show impaired autoinduction of TGF- $\beta 1$, the smaller influx of inflammatory cells probably contributes secondarily to the lower expression of TGF- $\beta 1$ after BDL.

A toxic bile salt, glycolchenodeoxycholate, has been suggested to have a role in BDL-induced hepatocyte apoptosis mediated through a Fas-dependent, but Fas ligand-independent pathway [33]. A previous study using Fas-deficient lpr (lymphoproliferation) mice indicated that BDL-induced hepatocyte apoptosis is mediated by Fas receptor activation until day 3 after BDL, but is replaced by a Fas-independent mechanism over time [34]. In this study, we demonstrated that hepatocyte apoptosis is elicited in wild-type mice, but not in Smad3null counterparts at day 3 and 7 after BDL. Since wild-type and Smad3null mice show the same extent of hyperbilirubinemia either day 3 or day 7 after BDL, the severity of cholestasis per se seems to be unrelated to the occurrence of hepatocyte apoptosis. Moreover, we observed that primary hepatocytes from lpr mice undergo a similar extent of TGF$\beta 1$-induced apoptosis as those derived from wild-type counterparts (data not shown), suggesting that there are no strong links between the TGF- $\beta 1$-induced apoptosis and the Fas death pathway in our BDL model. TGF- $\beta$ is known to be a potent inducer of apoptosis and a growth suppressor in a variety of epithelial cells [35]. TGF- $\beta 1$-induced hepatocyte apoptosis has been extensively studied both in vivo and in vitro $[10,11,36,37]$. Investigation of primary hepatocytes from wildtype or Smad3-null mice confirmed that TGF- $\beta 1$-induced apoptosis and growth arrest are mediated through the Smad3 signaling pathway. Since deficiency of Smad3 blocks hepatocyte apoptosis along with counteracting upregulation of hepatic TGF- $\beta 1$ after BDL, we concluded that the TGF- $\beta 1 /$ Smad 3 signaling pathway plays a principal role in BDL-induced hepatocyte apoptosis.

It was previously reported that $\mathrm{Smad} 3$ signaling is required for maximal expression of type I collagen in culture-activated HSC isolated from the livers of Smad3-null or wild-type mice [38]. More recently, a study using primary culture of HSC with adenovirally mediated wild-type and dominant-negative expression of Smad2 or Smad3 showed that Smad3 is a direct mediator of ECM production and plays an essential role in myofibroblastic transition associated with the development of focal adhesion and organization of $\alpha$-SMA in stress fibers [39]. Although HSC are widely thought to be the major ECMproducing cells [4], other hepatic mesenchymal cells such as portal myofibroblasts can also acquire fibrogenic capacity and take part in hepatic fibrogenesis [6,7]. Extensive studies performed in recent years indicate that portal fibroblasts and hematopoietic stem cells also gain fibrogenic properties in response to damaging stimuli during hepatic fibrogenesis [40-42]. Biliary epithelial cells have been shown to release paracrine mediators including TGF- $\beta 1$ that target portal mesenchymal cells during BDL-induced hepatic injury [43]. These reports suggest that a complex interplay among a variety of cell types takes place in hepatic fibrosis and tissue remodeling.

The present study demonstrated that periductal fibrogenic myofibroblasts are responsible for portal fibrogenesis during BDO in a Smad3-dependent manner. Our additional finding of concominant loss of E-cadherin and induction of Snail expression after BDL in Smad3 wild-type, but not null mice, suggests that biliary epithelial cells may undergo the Smad3-dependent EMT [44,45] as seen in the case of lens epithelial cells [18] and renal tubular epithelial cells [19]. The extent to which EMT mediates fibrosis in the liver is controversial. Lineage tracing experiments suggest that cholangiocytes do not undergo EMT in models of liver fibrosis $[46,47]$. However in the study by Scholten 
Citation: Sato M, Flanders KC, Matsubara T, Muragaki Y, Saika S, et al. (2014) Smad3 Deficiency Counteracts Hepatocyte Apoptosis and Portal Fibrogenesis Induced By Bile Duct Ligation. J Liver 3: 145. doi:10.4172/2167-0889.1000145

et al. [46] the low efficiency of genetic labeling makes it difficult to exclude the possibility that EMT occurred in a remaining population of unlabeled cells [48]. Additionally, the relatively short duration of these experimental injury models may not reflect the cellular pathophysiology that occurs in chronic human disease [49]. Indeed, two groups $[50,51]$ have shown that in tissue sections from patients with primary biliary cirrhosis many cells within a ductular reaction co-express both the epithelial marker CK7 and the fibroblast marker S100A4 (the human homologue of fibroblast-specific protein-1). This represents a potentially motile population of cells with an epithelial phenotype undergoing localized EMT.

Since hepatic TGF- $\beta 1$ expression after BDL in wild-type mice greatly exceeds that in Smad3-null counterparts, it is reasonable to assume that wild-type biliary epithelial cells are prone to undergo TGF- $\beta 1$-driven EMT in the process of portal fibrosis following BDL. Primary culture of intrahepatic biliary epithelial cells from wild-type or Smad3-null mice confirmed that TGF- $\beta 1$ induces EMT through Smad3 signaling pathway, suggesting that biliary epithelial cells may serve as a potential precursor for fibrogenic myofibroblasts during the pathogenesis of portal fibrosis in response to a wide range of stimuli, either cholestatic or inflammatory, that augment TGF- $\beta 1$ activity. In support of our findings knock-down of Smad 2/3 by siRNA in human intrahepatic biliary epithelial cells treated with LPS reverses EMT as shown by an up-regulation of E-cadherin and a down-regulation of S100A and $\alpha$-SMA [52].

\section{Conclusion}

In summary, the present study demonstrates that selective ablation of the Smad3 signaling pathway blocks the BDL-induced upregulation of hepatic TGF- $\beta 1$, apoptosis of hepatocytes and portal fibroproliferative response, abolishing hepatocellular damage and pathological accumulation of extracellular matrix proteins, while preserving other Smad3-independent TGF- $\beta 1$ signaling pathways. This provides a therapeutic rationale for the development of putative low molecular-weight inhibitors of Smad3 which have presumably fewer side effects than either anti-ligand or anti-receptor agents, which completely block downstream signaling of TGF- $\beta 1$ [53]. One such inhibitor, halofuginone, inhibits Smad2/3 signaling in a variety of cell types [54], including HSCs, and decreases collagen synthesis in a rat model of thioacetamide-induced liver fibrosis [55]. This supports our data suggesting that selective inhibition of the Smad3 pathway has the potential to prove highly effective in a wide range of hepatic disorders, including not only cholestatic liver disease, but also viral hepatitis and alcoholic liver disease.

\section{Acknowledgements}

We are very grateful to the late Dr. Anita B. Roberts for her suggestions and encouragement. We also thank Mario Anzano for his help with the Smad3-null mice. This study was partly supported by a grant from Hayashi Memorial Foundation for Female Natural Scientists (to M. Sato) and the 2004 Wakayama Medical Society Award for Young Researchers (to M. Sato).

\section{References}

1. Friedman SL (2003) Liver fibrosis -- from bench to bedside. J Hepatol 38 Suppl 1: S38-53.

2. Bataller R, Brenner DA (2005) Liver fibrosis. J Clin Invest 115: 209-218.

3. Ramadori G, Saile B (2004) Portal tract fibrogenesis in the liver. Lab Invest 84 : 153-159.

4. Friedman SL, Roll FJ, Boyles J, Bissell DM (1985) Hepatic lipocytes: the principal collagen-producing cells of normal rat liver. Proc Natl Acad Sci U S A 82: 8681-8685.
5. Gäbele E, Brenner DA, Rippe RA (2003) Liver fibrosis: signals leading to the amplification of the fibrogenic hepatic stellate cell. Front Biosci 8: d69-77.

6. Tuchweber B, Desmoulière A, Bochaton-Piallat ML, Rubbia-Brandt L, Gabbian G (1996) Proliferation and phenotypic modulation of portal fibroblasts in the early stages of cholestatic fibrosis in the rat. Lab Invest 74: 265-278.

7. Kinnman N, Francoz C, Barbu V, Wendum D, Rey C, et al. (2003) The myofibroblastic conversion of peribiliary fibrogenic cells distinct from hepatic stellate cells is stimulated by platelet-derived growth factor during liver fibrogenesis. Lab Invest 83: 163-173.

8. Blobe GC, Schiemann WP, Lodish HF (2000) Role of transforming growth factor beta in human disease. N Engl J Med 342: 1350-1358.

9. Gressner AM, Weiskirchen R, Breitkopf K, Dooley S (2002) Roles of TGF-beta in hepatic fibrosis. Front Biosci 7: d793-807.

10. Sanderson N, Factor V, Nagy P, Kopp J, Kondaiah P, et al. (1995) Hepatic expression of mature transforming growth factor beta 1 in transgenic mice results in multiple tissue lesions. Proc Natl Acad Sci U S A 92: 2572-2576.

11. Clouthier DE, Comerford SA, Hammer RE (1997) Hepatic fibrosis glomerulosclerosis, and a lipodystrophy-like syndrome in PEPCK-TGF-beta1 transgenic mice. J Clin Invest 100: 2697-2713.

12. Massagué $\mathrm{J}$ (2008) TGFbeta in Cancer. Cell 134: 215-230.

13. Heldin CH, Landström M, Moustakas A (2009) Mechanism of TGF-beta signaling to growth arrest, apoptosis, and epithelial-mesenchymal transition. Curr Opin Cell Biol 21: 166-176.

14. Qi Z, Atsuchi N, Ooshima A, Takeshita A, Ueno H (1999) Blockade of type beta transforming growth factor signaling prevents liver fibrosis and dysfunction in the rat. Proc Natl Acad Sci U S A 96: 2345-2349.

15. Nakamura T, Sakata R, Ueno T, Sata M, Ueno H (2000) Inhibition of transforming growth factor beta prevents progression of liver fibrosis and enhances hepatocyte regeneration in dimethylnitrosamine-treated rats. Hepatology 32 : 247-255.

16. Roberts AB, Russo A, Felici A, Flanders KC (2003) Smad3: a key player in pathogenetic mechanisms dependent on TGF-beta. Ann N Y Acad Sci 995: 1-10.

17. Flanders KC (2004) Smad3 as a mediator of the fibrotic response. Int J Exp Pathol 85: 47-64

18. Saika S, Kono-Saika S, Ohnishi Y, Sato M, Muragaki Y, et al. (2004) Smad3 signaling is required for epithelial-mesenchymal transition of lens epithelium after injury. Am J Pathol 164: 651-663.

19. Sato M, Muragaki Y, Saika S, Roberts AB, Ooshima A (2003) Targeted disruption of TGF-beta1/Smad3 signaling protects against renal tubulointerstitial fibrosis induced by unilateral ureteral obstruction. J Clin Invest 112: 1486-1494.

20. Yang X, Letterio JJ, Lechleider RJ, Chen L, Hayman R, et al. (1999) Targeted disruption of SMAD3 results in impaired mucosal immunity and diminished $T$ cell responsiveness to TGF-beta. EMBO J 18: 1280-1291.

21. Gjessing R, Seglen PO (1980) Adsorption, simple binding and complex binding of rat hepatocytes to various in vitro substrata. Exp Cell Res 129: 239-249.

22. Böhme K, Li Y, Oh PS, Olsen BR (1995) Primary structure of the long and short splice variants of mouse collagen XII and their tissue-specific expression during embryonic development. Dev Dyn 204: 432-445.

23. Kivirikko KI, Laitinen O, Prockop DJ (1967) Modifications of a specific assay for hydroxyproline in urine. Anal Biochem 19: 249-255.

24. Nieto MA (2002) The snail superfamily of zinc-finger transcription factors. Nat Rev Mol Cell Biol 3: 155-166.

25. Cano A, Pérez-Moreno MA, Rodrigo I, Locascio A, Blanco MJ, et al. (2000) The transcription factor snail controls epithelial-mesenchymal transitions by repressing E-cadherin expression. Nat Cell Biol 2: 76-83.

26. Ramm GA, Nair VG, Bridle KR, Shepherd RW, Crawford DH (1998) Contribution of hepatic parenchymal and nonparenchymal cells to hepatic fibrogenesis in biliary atresia. Am J Pathol 153: 527-535.

27. Czaja MJ, Weiner FR, Flanders KC, Giambrone MA, Wind R, et al. (1989) In vitro and in vivo association of transforming growth factor-beta 1 with hepatic fibrosis. J Cell Biol 108: 2477-2482.

28. Seyhan H, Hamzavi J, Wiercinska E, Gressner AM, Mertens PR, et al. (2006) 
Citation: Sato M, Flanders KC, Matsubara T, Muragaki Y, Saika S, et al. (2014) Smad3 Deficiency Counteracts Hepatocyte Apoptosis and Portal Fibrogenesis Induced By Bile Duct Ligation. J Liver 3: 145. doi:10.4172/2167-0889.1000145

Liver fibrogenesis due to cholestasis is associated with increased Smad7 expression and Smad3 signaling. J Cell Mol Med 10: 922-932.

29. Bissell DM, Wang SS, Jarnagin WR, Roll FJ (1995) Cell-specific expression of transforming growth factor-beta in rat liver. Evidence for autocrine regulation of hepatocyte proliferation. J Clin Invest 96: 447-455.

30. Ashcroft GS, Yang X, Glick AB, Weinstein M, Letterio JL, et al. (1999) Mice lacking Smad3 show accelerated wound healing and an impaired local inflammatory response. Nat Cell Biol 1: 260-266.

31. Piek E, Ju WJ, Heyer J, Escalante-Alcalde D, Stewart CL, et al. (2001) Functional characterization of transforming growth factor beta signaling in Smad2- and Smad3-deficient fibroblasts. J Biol Chem 276: 19945-19953.

32. Wahl SM, Hunt DA, Wakefield LM, McCartney-Francis N, Wahl LM, et al. (1987) Transforming growth factor type beta induces monocyte chemotaxis and growth factor production. Proc Natl Acad Sci U S A 84: 5788-5792.

33. Faubion WA, Guicciardi ME, Miyoshi H, Bronk SF, Roberts PJ, et al. (1999) Toxic bile salts induce rodent hepatocyte apoptosis via direct activation of Fas. J Clin Invest 103: 137-145.

34. Miyoshi H, Rust C, Roberts PJ, Burgart LJ, Gores GJ (1999) Hepatocyte apoptosis after bile duct ligation in the mouse involves Fas. Gastroenterology 117: 669-677.

35. Siegel PM, Massagué J (2003) Cytostatic and apoptotic actions of TGF-beta in homeostasis and cancer. Nat Rev Cancer 3: 807-821.

36. Franco DL, Mainez J, Vega S, Sancho P, Murillo MM, et al. (2010) Snail suppresses TGF-beta-induced apoptosis and is sufficient to trigger EMT in hepatocytes. J Cell Sci 123: 3467-3477.

37. Yoo J, Ghiassi M, Jirmanova L, Balliet AG, Hoffman B, et al. (2003) Transforming growth factor-beta-induced apoptosis is mediated by Smaddependent expression of GADD45b through p38 activation. J Biol Chem 278 : 43001-43007.

38. Schnabl B, Kweon YO, Frederick JP, Wang XF, Rippe RA, et al. (2001) The role of Smad3 in mediating mouse hepatic stellate cell activation. Hepatology 34: 89-100.

39. Uemura M, Swenson ES, Gaça MD, Giordano FJ, Reiss M, et al. (2005) Smad2 and Smad3 play different roles in rat hepatic stellate cell function and alphasmooth muscle actin organization. Mol Biol Cell 16: 4214-4224.

40. Knittel T, Kobold D, Saile B, Grundmann A, Neubauer K, et al. (1999) Rat liver myofibroblasts and hepatic stellate cells: different cell populations of the fibroblast lineage with fibrogenic potential. Gastroenterology 117: 1205-1221.

41. Magness ST, Bataller R, Yang L, Brenner DA (2004) A dual reporter gene transgenic mouse demonstrates heterogeneity in hepatic fibrogenic cell populations. Hepatology 40: 1151-1159.
42. Forbes SJ, Russo FP, Rey V, Burra P, Rugge M, et al. (2004) A significant proportion of myofibroblasts are of bone marrow origin in human liver fibrosis. Gastroenterology 126: 955-963.

43. Kinnman N, Housset C (2002) Peribiliary myofibroblasts in biliary type liver fibrosis. Front Biosci 7: d496-503.

44. Iwano M, Plieth D, Danoff TM, Xue C, Okada H, et al. (2002) Evidence that fibroblasts derive from epithelium during tissue fibrosis. J Clin Invest 110: 341 350.

45. Kalluri R, Neilson EG (2003) Epithelial-mesenchymal transition and its implications for fibrosis. J Clin Invest 112: 1776-1784.

46. Chu AS, Diaz R, Hui JJ, Yanger K, Zong Y, et al. (2011) Lineage tracing demonstrates no evidence of cholangiocyte epithelial-to-mesenchymal transition in murine models of hepatic fibrosis. Hepatology 53: 1685-1695.

47. Scholten D, Osterreicher CH, Scholten A, Iwaisako K, Gu G, et al. (2010) Genetic labeling does not detect epithelial-to-mesenchymal transition of cholangiocytes in liver fibrosis in mice. Gastroenterology 139: 987-998.

48. Popov Y, Schuppan D (2010) Epithelial-to-mesenchymal transition in liver fibrosis: dead or alive? Gastroenterology 139: 722-725.

49. Kisseleva T, Brenner DA (2011) Is it the end of the line for the EMT? Hepatology 53: $1433-1435$

50. Omenetti A, Porrello A, Jung Y, Yang L, Popov Y, et al. (2008) Hedgehog signaling regulates epithelial-mesenchymal transition during biliary fibrosis in rodents and humans. J Clin Invest 118: 3331-3342.

51. Rygiel KA, Robertson H, Marshall HL, Pekalski M, Zhao L, et al. (2008) Epithelial-mesenchymal transition contributes to portal tract fibrogenesis during human chronic liver disease. Lab Invest 88: 112-123.

52. Zhao L, Yang R, Cheng L, Wang M, Jiang Y, et al. (2011) LPS-induced epithelial-mesenchymal transition of intrahepatic biliary epithelial cells. J Surg Res 171: 819-825.

53. Peters $\mathrm{H}$, Noble NA, Border WA (1997) Transforming growth factor-beta in human glomerular injury. Curr Opin Nephrol Hypertens 6: 389-393.

54. Xavier S, Piek E, Fujii M, Javelaud D, Mauviel A, et al. (2004) Amelioration of radiation-induced fibrosis: inhibition of transforming growth factor-beta signaling by halofuginone. J Biol Chem 279: 15167-15176.

55. Gnainsky Y, Kushnirsky Z, Bilu G, Hagai Y, Genina O, et al. (2007) Gene expression during chemically induced liver fibrosis: effect of halofuginone on TGF-beta signaling. Cell Tissue Res 328: 153-166. 